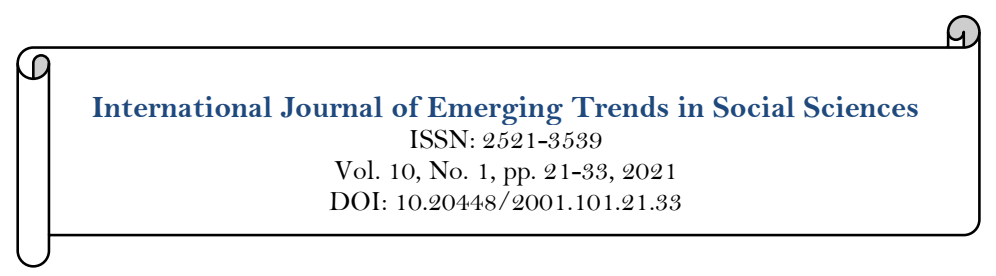

\title{
Research on Resource Allocation Effect of China's OFDI on Equipment Manufacturing Industry
}

\section{Shaogui Chen}

Economics Department, Central University of Finance and Economics, China. Email:gxnncsg@sina.com

\begin{tabular}{|c|c|}
\hline Abstract & \\
\hline $\begin{array}{l}\text { Based on the panel data and time series data of China's } 30 \text { provinces } \\
\text { (excluding Tibet) from } 2004 \text { to } 2017 \text {, this paper analyzes the impact of } \\
\text { China's OFDI on the resource allocation effect of equipment manufacturing } \\
\text { industry through regression model. The empirical results show that China's } \\
\text { OFDI has a significant positive effect on the resource allocation effect of } \\
\text { equipment manufacturing industry, and with every unit of China's OFDI } \\
\text { increasing, the profit margin of main business (PMB) of the equipment } \\
\text { manufacturing industry will increase O.O87 percentage points. From the } \\
\text { regional point of view, the growth of OFDI in Northeast China has a } \\
\text { significant positive impact on the PMB of the equipment manufacturing } \\
\text { industry, and its positive impact is the largest, followed by the eastern region, } \\
\text { and the central and western regions have a significant negative impact. } \\
\text { From the perspective of OFDI gradient, China's forward OFDI to } \\
\text { developing countries and reverse OFDI to developed countries have a } \\
\text { significant positive impact on the PMB of equipment manufacturing } \\
\text { industry, and the impact of forward OFDI is more significant. Finally, this } \\
\text { paper puts forward some suggestions on how to improve the efficiency of } \\
\text { China's equipment manufacturing industry. }\end{array}$ & $\begin{array}{l}\text { Licensed: } \\
\text { This work is licensed under a } \\
\text { Creative Commons Attribution } 4.0 \\
\text { License. } \\
\text { Publisher: } \\
\text { Scientific Publishing Institute } \\
\text { Received: } 25 \text { November } 2020 \\
\text { Revised: } 14 \text { December } 2020 \\
\text { Accepted: 4 January } 2021 \\
\text { Published: } 1 \text { February } 2021\end{array}$ \\
\hline
\end{tabular}

Funding: This study received no specific financial support.

Competing Interests: The author declares that there are no conflicts of interests regarding the publication of this paper.

\section{Introduction}

At present, despite the surging trend of anti globalization in Europe and the United States, economic globalization is still the main trend of global economic development in today's world. The flow of production factors is the essential feature of economic globalization. The essence of outward foreign direct investment is the international flow of production factors with capital as the carrier. Outward foreign direct investment is still the main factor driving economic globalization. In order to adapt to the profound and complex changes faced by the economic and social development environment, China timely proposed to " to construct a new development pattern in which the domestic great cycle is the main body and the domestic and international double cycles promote each other ", that is to better coordinate the domestic and international markets and resources, and improve the ability and level of global resource allocation. In the past decade, China's outward foreign direct investment has developed rapidly, which has provided convenient conditions for China's global resource allocation. According to the data of China's outward foreign direct investment statistical bulletin, from the perspective of two-way investment, China's outward foreign direct investment (OFDI) exceeded the actual foreign investment (FDI) for four consecutive years from 2015 to 2018 , and China has begun to become 
a net capital exporter. Especially in recent years, China has been ranked in the top three of global OFDI flows for seven consecutive years, and OFDI has continuously become a booster of China's global resource allocation.

For a long time, as an important part of China's economic development, the manufacturing industry is the leading industry and pillar industry of the national economy. Equipment manufacturing industry is the "mother machine" of other industries. The development of equipment manufacturing industry is the precondition of realizing the comprehensive industry modernization. At present, the development of domestic equipment manufacturing industry is faced with multiple constraints such as resources and environment, great pressure from environmental protection, rising labour prices, no longer the advantage of labour cost, low content of science and technology, shortage of strategic resources such as technology and brand, and weak international competitiveness. Therefore, it is urgent to "go out of capital" to coordinate from domestic and international markets and two kinds of resources to resolve the development pressure, enhance international competitiveness, and promote the equipment manufacturing industry to the high end of the global value chain. Therefore, it is of practical significance to study the resource allocation effect of China's OFDI on the equipment manufacturing industry.

\section{Literature Review}

2.1. Research on Outward Foreign Direct Investment

As for the definition of outward foreign direct investment (OFDI), the International Monetary Fund (IMF) believes that OFDI refers to an investment activity in which a country engages in production and operation abroad and obtains sustainable income, and its main purpose is to have the management right of overseas enterprises (IMF, 2001). The organization for economic cooperation and development (OECD) pointed out that the so-called outward foreign direct investment refers to the investment activities that can obtain economic benefits and effectively control them by establishing long-term strategic cooperative relations with enterprises of other countries (United Nations Conference on Trade and Development World Investment Report, 1996). China's Ministry of Commerce believes that outward foreign direct investment is an economic activity in which domestic investors in China set up and purchase enterprises abroad and in Hong Kong, Macao and Taiwan in the form of physical, cash or intangible assets, control $10 \%$ or more of the equity of the enterprise, and control its operation and management power as the core goal (Ministry of Commerce, 2008). This paper mainly refers to the formulation of the Ministry of Commerce of China, and thinks that outward foreign direct investment is the behaviour of multinational enterprises to invest in cash, physical, intangible assets and other ways in order to obtain effective control over the operation and management of foreign enterprises.

Outward foreign direct investment first appeared in developed countries. With the development of economic globalization, some developing countries, especially emerging economies, have also begun to invest abroad, integrating into the trend of transnational flow of production factors and global allocation of factor resources. Therefore, extensive research on the theory and practice of outward foreign direct investment has sprung up in academic circles. At present, the theoretical research on outward foreign direct investment is relatively mature, and the views are relatively unified, which will not be elaborated here. From the perspective of practical research, the research on OFDI at home and abroad mainly focuses on the investment motivation, location selection, and impact of OFDI, especially in the fields of home country trade, employment, industrial upgrading, and technological progress.

As for the motivation and location choice of OFDI, Dunning (1977) thinks that the motivation of OFDI can be divided into four types: one is resource seeking type, and the purpose of outward foreign direct investment is to obtain foreign natural resources with lower cost; the second is the market seeking type, in which enterprises exploit the market through outward foreign direct investment and produce the same products and services in different countries to maximize profits; the third is the efficiency seeking type, in which enterprises will seek suitable regions for factor prices due to the differences in factor prices in different countries and regions, integrate domestic and foreign production, so as to improve their own production efficiency and level; the fourth is the strategic asset seeking type, whose investment purpose is to obtain the scarce resources in the domestic market, such as technology, patent, brand, marketing network, etc., which can give the enterprise competitive advantage. Kojima and Zhou (1987) believes that the motivation of OFDI can be divided into three types: natural resource seeking type, production factor seeking type and market seeking type. Yu-Guansheng (2014) a domestic scholar, compared the motives of foreign direct investment of enterprises in developed countries and developing countries. He hold that the motives of OFDI of enterprises in developed countries were more concentrated, mainly considering the location factors of investment target countries; while the motives of developing countries were more influenced by the foreign and investment policies of home countries. Some scholars list the technology seeking factors in strategic asset seeking as a motivation. Regardless of the research perspective, most studies believe that resource seeking and market seeking OFDI are mainly invested in developing countries, while technology seeking and strategic asset seeking OFDI are mainly invested in developed countries. 
On the impact of OFDI on home country trade and employment, research by Li and Wang (2015) shows that China's OFDI has a significant role in promoting the improvement of home country trade structure. From a regional perspective, among the eastern, central and western regions, the trade structure effect of OFDI in the Eastern region is the most obvious. Yang (2004) proves that, on the whole, the home country's employment is affected by outward foreign direct investment, and has a positive role in promoting.

As for the research on the relationship between OFDI and industrial upgrading, scholars mainly focus on whether there is interaction between them and whether the effect is positive or negative. Based on different research perspectives and methods, scholars at home and abroad have come to different conclusions. To sum up, there are three main categories. The first is that outward foreign direct investment can significantly promote the industrial upgrading of the home country. Most studies show that OFDI can promote the industrial upgrading of home country. Adler (1974) believes that outward foreign direct investment can not only improve the added value of enterprise products, but also promote the industrial upgrading of the home country. According to the research of UNCTAD, outward foreign investment can significantly enhance the industrial competitiveness of developing countries, and significantly enhance the overall development level and competitive advantage of related industries through technology spillover effect and correlation effect. Based on the domestic empirical data, domestic scholars also study and analyze the impact of China's outward foreign direct investment on industrial upgrading. Huo (2014) insists that OFDI of China's three industries has a significant impact on domestic industrial structure adjustment, and has a more significant impact on technology intensive and labour-intensive industries. The second is that OFDI has no significant effect on the industrial upgrading of the home country. A few scholars believe that the promotion effect of outward foreign direct investment on the industrial structure optimization of the home country is not significant, or even does not exist. The third type is that OFDI hinders the industrial upgrading of the home country. It is believed that OFDI brings the "hollowing out" of the home country's industry, which will lead to the decline of related industries in the home country.

Research on the impact of outward foreign direct investment on the home country's technological progress. From the research results, scholars have different views, which can be roughly divided into three categories: the first category believes that OFDI can significantly promote the technological progress of the home country through reverse technology spillover effect. Foreign scholars Kogut and Chang (1991); Teece (1992) and Potterie and Lichtenbe (2001) have empirically proved that OFDI has reverse technology spillover effect from the enterprise level and national level, and OFDI has significant spillover effect on domestic productivity. Domestic scholars Liu-Mingxia (2010); Guo and Huang (2012); Song (2015) and Han and Wang (2016) find that China's OFDI has significant reverse technology spillover effect from the industrial level and the national level, and has a significant role in promoting the technological progress expressed by total factor productivity. Second, the technology spillover effect is not significant. The third category thinks that the reverse technology spillover effect of OFDI can promote the technological progress of the home country, but it needs certain preconditions to achieve, and the reverse technology spillover effect of OFDI will be significant only after reaching a certain threshold level.

\subsection{Research on Resource Allocation}

On the meaning of resources. $\mathrm{Hu}$ (2017) believes that there are two categories in narrow sense and broad sense: narrow sense refers to land, minerals, air, water, sunlight and other natural materials necessary for human production and life, which can also be called natural resources; broad sense refers to economic and social resources on the basis of narrow sense, in which economic resources include capital, labour force and social resources It can also be said that the broad category of resources includes natural resources, economic and social resources. Guo (2017) thinks that under certain production conditions, resources can be developed and utilized for people, and the material and spiritual wealth created through productive labour in economic activities can also be called production factors. Zhang and $\mathrm{Wu}$ (2017) believe that global resource allocation is to optimize the combination of global production factors, and resources can also be called production factors. From the perspective of investment country, production factors include monetary capital, product design, technology, brand, patent, operation and management, marketing network, high-end talents, etc.; from the perspective of host country, production factors are land, labour and resources Industrial support, incentive policies and business environment. This paper defines the meaning of resources from the perspective of economics. Resources refer to the resources that can be used as production factors, including capital, labour, land, minerals and other physical production factors, as well as the abstract form of technology, patents, brands, management knowledge, marketing network and other advanced production factors.

On the meaning of resource allocation. Economics takes the research of resource allocation as its theme. The so-called resource allocation means that under certain economic conditions, the flow and combination of various factors of production can optimize the total economic output and reach a maximum in quantity, that is, Pareto optimization. Lai (2019) believes that under the premise of certain production factors such as capital and labour, how to make them distribute among industries, enterprises and even within enterprises will affect the total output of the economy. In the long run, the optimal allocation can maximize social welfare or output. Deviation from this optimal allocation is called resource misallocation or resource mismatch, which will lead to lower output level. 
Many domestic scholars study the efficiency of resource allocation from the perspective of resource mismatch. Chen and $\mathrm{Hu}$ (2011) introduced the factor mismatch analysis in growth accounting for the first time. The research shows that the factor resource mismatch does not maximize the actual output of China's manufacturing industry, and there is a $15 \%$ gap between the actual output and the potential output. Gong and $\mathrm{Hu}(2013)$ found that if the capital and labour of China's manufacturing sector reach the optimal allocation, TFP will increase by $57.1 \%$ in 1998 and $30.1 \%$ in 2007. Ji, Zhu, and Zhang (2016) calculated the resource mismatch index of China's sub industries, and found that $72 \%$ of the industries had insufficient capital allocation and $69 \%$ had excessive labour allocation. In capital intensive industries, capital allocation is generally excessive; in labour-intensive industries, capital allocation is generally insufficient; in technology intensive industries, labour allocation gap is obvious. Zhang and Zhao (2018) calculated the degree of capital and labour distortions in China's provinces and industries, and found that during 2004-2013, the degree of capital distortions in China continued to deteriorate, while the situation of labour distortions improved, and the degree of capital distortions was far greater than that of labour distortions. In addition, from the regional point of view, the distortion degree of resources in the northeast and midwest is significantly greater than that in the eastern region.

\subsection{Research on the Impact of Outward Foreign Direct Investment on Industry Resource Allocation Efficiency}

As early as the end of the last century, Hiley (1999) found through the study of Japan's outward foreign direct investment from the 1970 s till 1990 s that, with the help of outward foreign direct investment, Japan transferred the textile industry and machinery industry, which are at a comparative disadvantage, to ASEAN countries with rich labour force and low cost, thus realizing the transfer of domestic production factors from inferior industries to superior industries, and improving the allocation efficiency of domestic production factor resources. Dai (2006) found that through outward foreign direct investment, Singapore's internal labor force had be reallocated, from production-oriented industries to technology intensive and management intensive industries, which improves the allocation efficiency of labour resources. Xie-Qiaoxin (2014) analyzed the relationship between China's OFDI and domestic capital allocation efficiency from both theoretical and empirical perspectives. The results show that the expansion of China's OFDI scale has a positive effect on the efficiency of domestic capital allocation. Cao (2017) believes that the global flow of capital has changed the spatial allocation of economic factor resources, which can help enterprises seek the optimal allocation of resources and maximize their own interests. There are mainly two types of resources that outward foreign direct investment enterprises seek, one is natural resources, the other is strategic resources. China's outward foreign direct investment promotes the upgrading of manufacturing industry by seeking domestic inferior natural resources to reduce costs and seeking foreign superior strategic resources to improve quality. Bai and Liu (2018) studied and analyzed the relationship between China's OFDI and resource mismatch. The empirical results show that OFDI can significantly improve China's overall resource mismatch, and there are regional differences. Lin and Chen (2020) investigated the impact of outward foreign direct investment on the resource allocation efficiency of China's industries through the data of agricultural processing enterprises in China's industrial enterprise database. The results show that OFDI can significantly promote the efficiency of resource allocation in China. And through the heterogeneity test, it shows that the role of outward foreign direct investment of market-oriented enterprises is positive, but the outward foreign direct investment of production substitution enterprises has a negative impact on the efficiency of resource allocation.

To sum up, scholars at home and abroad have conducted extensive research on outward foreign direct investment, resource allocation, and the impact of outward foreign direct investment on resource allocation. But on the whole, previous studies tend to focus on the impact of OFDI on trade economy, industrial upgrading and technological progress. Most scholars focus on the efficiency of resource allocation rather than the result of resource allocation. The research on the impact of OFDI on resource allocation mainly focuses on the impact of OFDI on the allocation of capital and labour in macroeconomic factors, while the research on the impact of OFDI on resource allocation of a certain industry is less, especially on the effect of OFDI on resource allocation of manufacturing industry, especially equipment manufacturing industry. Therefore, this paper studying the resource allocation of China's OFDI on equipment manufacturing industry Allocation effect seems particularly important.

\section{Mechanism Analysis of OFDI's Influence on Resource Allocation Effect of Manufacturing Industry}

The resource of production factors is an important basis for a country to carry out economic activities. Similarly, the development of a country's manufacturing industry, on the one hand, needs domestic limited factor resources as support, on the other hand, also needs to make full use of foreign resources as an important supplement. Therefore, with the deep development of economic globalization, it is necessary to allocate resources rationally and improve the efficiency of resource utilization. In an open economy, outward foreign direct investment provides an effective way for the free flow of production factor resources in the global scope, enabling production factors to flow across the border and participate in the international division of labor, so as to realize the optimal allocation of resources in the global scope. It is through the transmission mechanism 
of promoting the free flow of production factors that OFDI can improve the resource allocation efficiency of China's manufacturing industry, promote the transformation and upgrading of manufacturing industry, and promote the high-quality development of manufacturing industry. According to the different motivations of domestic and foreign scholars on OFDI, the OFDI behaviour of enterprises can be roughly divided into four types: resource seeking type, market seeking type, efficiency seeking type and strategic asset seeking type. From the perspective of the motivation of outward foreign direct investment, this paper analyzes the influence mechanism of foreign direct investment on the resource allocation effect of manufacturing industry, as shown in Figure 1.

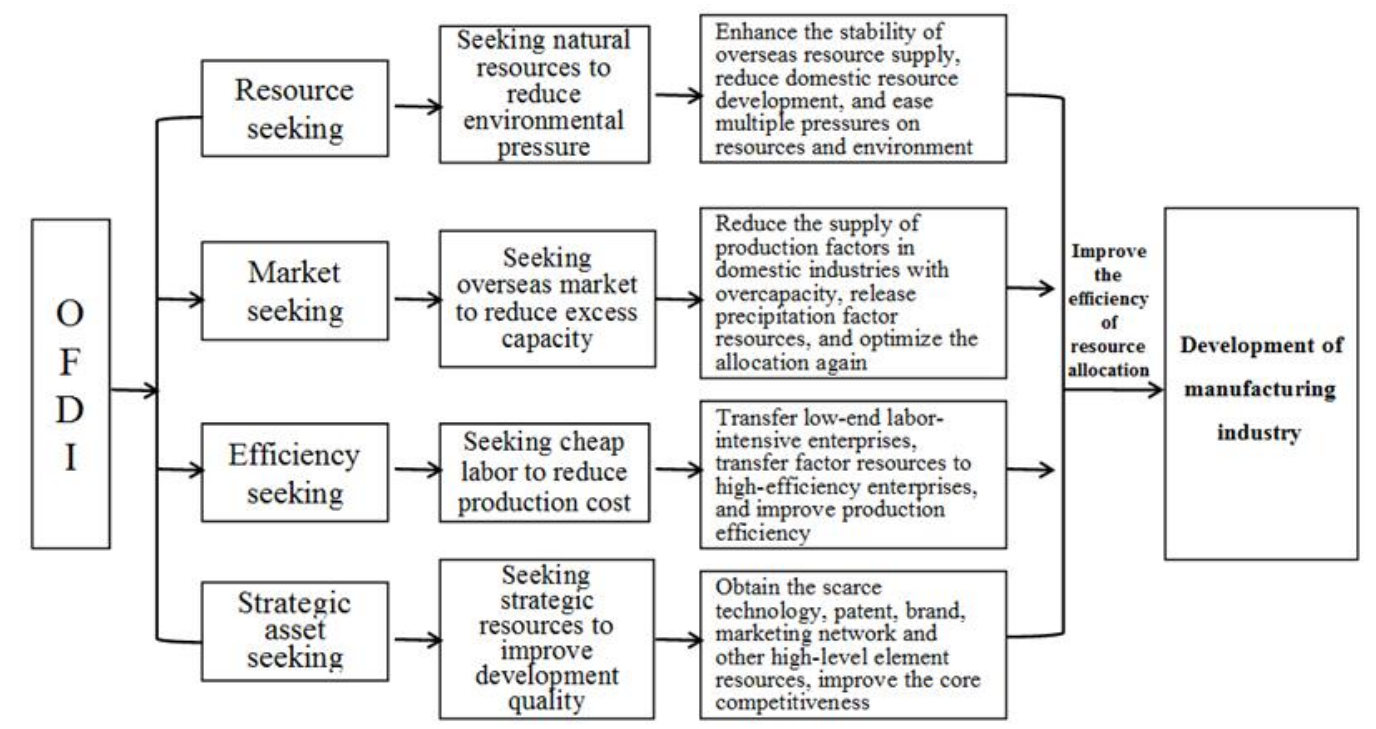

Figure-1. The influence mechanism of OFDI on the resource allocation effect of manufacturing industry.

\subsection{Resource Seeking}

Resource seeking OFDI mainly refers to foreign investment activities motivated by the acquisition of cheap minerals, oil and other natural resources. With the continuous growth of global population and rapid economic development, human demand for natural resources is increasing. At present, in many industrialized countries and regions, there is a shortage of natural resources, and even some resources are facing exhaustion. One of the biggest reasons for China's OFDI is to seek natural resources. In recent 10 years, the speed of China's economic growth has exerted great pressure on the domestic natural resource reserves, which can not meet the growing demand. In addition, the per capita share is small, the development cost is high, and some resources are still in short supply. The raw materials needed by the manufacturing industry, such as mineral resources and energy, need to be imported from abroad. Therefore, the industry distribution of China's enterprises' OFDI is resource oriented. According to the data of China's Outward Foreign Direct Investment Statistical Bulletin, from 2004 to 2017, the mining industry accounted for an average of $14.1 \%$ of the total foreign investment in the stock of China's outward foreign direct investment. In the 19 industry categories of outward foreign direct investment, its ranking is basically in the third place, only next to the leasing and commercial services industry, wholesale and retail industry and financial industry.

The effects of resource seeking OFDI and seeking natural resources to reduce environmental pressure are mainly reflected in the following aspects: in countries and regions with better natural resources endowment, multinational enterprises establish relatively stable resource supply channels through outward foreign direct investment, reduce the market risk of resource acquisition, enhance the stability of overseas resource supply, and obtain key resources needed for industrial development. At the same time, it can reduce the development of domestic resources, ease the pressure of multiple constraints on domestic resources and environment, break the resource bottleneck, provide resource support and guarantee for the development of manufacturing industry, and promote the development of manufacturing industry.

\subsection{Market Seeking}

Since the 21 st century, the phenomenon of repeated construction and overcapacity in China has begun to appear, the production capacity and effective demand do not match, the economic activities do not reach the normal output level, the resources are not fully utilized, the resources are not reasonably utilized, and the production capacity is idle to some extent. Overcapacity is actually the external manifestation of low efficiency of resource allocation, which leads to the deterioration of industrial organization, the decline of enterprise profits, the increase of financial risks and the serious waste of resources.

The effect of market seeking OFDI and seeking overseas market to reduce excess capacity is mainly reflected in: through outward foreign direct investment, some production factors of multinational enterprises 
realize transnational flow, effectively alleviate the domestic over investment, and provide an effective path for transferring excess capacity and improving the efficiency of resource allocation. Enterprises carry out OFDI to transfer the production of overcapacity industries to overseas, reduce the supply of production factors in domestic overcapacity industries, alleviate the phenomenon of capacity accumulation, release the precipitation factor resources, improve the factor mismatch, realize the optimization and reallocation of production factors, improve the factor allocation efficiency of domestic manufacturing enterprises, and promote the development of manufacturing industry.

\subsection{Efficiency Seeking}

Efficiency seeking OFDI refers to the outward investment activities to improve production efficiency. Efficiency seeking OFDI is mainly to seek cheap labour resources, reduce production costs and improve production efficiency. Its effects are mainly reflected in: relying on their own comparative advantages, multinational enterprises re integrate factor resources in the global scope, transfer labour-intensive enterprises to countries and regions with rich labour resources, use cheap foreign resources and skilled labour, reduce production costs, promote enterprises to increase revenue and reduce expenditure, and have the ability to increase $\mathrm{R} \& \mathrm{D}$ investment and promote enterprise development Industrial products and process upgrading, improve enterprise production efficiency. At the same time, release a large number of production factors occupied by low efficiency enterprises, transfer to high efficiency enterprises, make high efficiency enterprises obtain more production factor resources, so as to promote the optimal allocation of resources and promote the development of manufacturing industry.

Experts believe that low-end labour-intensive industries sensitive to labour prices have obvious gradient transfer. With the continuous refinement of the international division of labour, through outward foreign direct investment, the traditional labour-intensive industries and high-tech industries labour-intensive processes have undergone gradient transfer. From the United States to Japan and South Korea, from Japan and South Korea to China, and now to Southeast Asia, where there are advantages in labour resources, it will turn to where.

China's comparative advantage is mainly concentrated in labour-intensive industries, and in the international division of labour, it is also mainly concentrated in the links with relatively low technology content. In recent years, China's labour cost is rising every year. One of the reasons is the shortage of migrant workers. As a result, with the increasing cost pressure on China's manufacturing industry, some factories in China's coastal areas have begun to seek cheap labour from overseas to reduce production costs. Asia, especially Southeast Asian countries, is rich and cheap in labour resources. Due to their similar cultures and geographical advantages, they have always been an important destination for foreign investment in China's labour-intensive manufacturing industry. It can be seen from Table 1 that since the establishment of the statistics system of China's outward foreign direct investment in 2003, Asia has always accounted for a large proportion of China's outward foreign direct investment in all continents, basically about $70 \%$, which also reflects the regional selection direction of China's outward foreign direct investment.

\begin{tabular}{c|c|c|c|c|c|c}
\multicolumn{7}{c}{ Table-1. Proportion of China's outward foreign direct investment stock by continent (unit:\%). } \\
\hline Year & Asia & Africa & Europe & Latin America & North America & Oceania \\
\hline 2003 & 80.08 & 1.48 & 1.47 & 13.9 & 1.65 & 1.42 \\
\hline 2004 & 74.77 & 2.01 & 1.51 & 18.47 & 2.03 & 1.21 \\
\hline 2005 & 71.59 & 2.79 & 2.23 & 20.05 & 2.21 & 1.14 \\
\hline 2006 & 63.95 & 3.41 & 3.03 & 26.25 & 2.12 & 1.25 \\
\hline 2007 & 67.18 & 3.78 & 3.78 & 20.95 & 2.75 & 1.55 \\
\hline 2008 & 71.38 & 4.24 & 2.79 & 17.52 & 1.99 & 2.07 \\
\hline 2009 & 75.5 & 3.8 & 3.53 & 12.45 & 2.11 & 2.61 \\
\hline 2010 & 71.92 & 4.11 & 4.95 & 13.83 & 2.47 & 2.71 \\
\hline 2011 & 71.43 & 3.82 & 5.76 & 12.99 & 3.17 & 2.83 \\
\hline 2012 & 68.51 & 4.08 & 6.95 & 12.82 & 4.79 & 2.84 \\
\hline 2013 & 67.74 & 3.96 & 8.05 & 13.04 & 4.33 & 2.88 \\
\hline 2014 & 68.09 & 3.67 & 7.86 & 12.02 & 5.43 & 2.93 \\
\hline 2015 & 70.04 & 3.16 & 7.62 & 11.51 & 4.75 & 2.92 \\
\hline 2016 & 67 & 2.94 & 6.42 & 15.26 & 5.56 & 2.82 \\
\hline 2017 & 62.98 & 2.39 & 6.13 & 21.39 & 4.8 & 2.31 \\
\hline Mean value & 70.14 & 3.31 & 4.81 & 16.16 & 3.34 & 2.23 \\
\hline
\end{tabular}

\subsection{Strategic Asset Seeking}

According to the definition of Baidu Encyclopedia, strategic assets refer to a group of resources and capabilities that can bring economic benefits to enterprises. Some experts believe that the so-called strategic assets refer to a group of unique resources and capabilities based on a common knowledge base, which can continuously produce competitive advantages, which are not easy to imitate or replace, and which have 
isolation mechanism, including brand, trademark, management, marketing, R\&D and other strategic elements. Global strategic assets are mainly concentrated in developed economies. One of the important reasons for Chinese enterprises' reverse investment in developed economies is to obtain strategic assets such as technology and brand. An important achievement since China's reform and opening up is the formation of a large amount of capital accumulation. However, it is difficult to form strategic asset elements such as patents and brands due to technology and talents. Therefore, the capital advantage has created conditions for China's outward foreign direct investment through international mergers and acquisitions. This kind of M\&A can quickly obtain the technology, patent, brand and international market network owned by enterprises in developed countries, alleviate the shortage of high-level factor resources, and achieve a rapid breakthrough in improving core competitiveness. This is the resource allocation effect of strategic asset seeking OFDI.

It can be seen from Table 1 that although the scale of China's investment in developed economies is small at present, the proportion of China's outward foreign direct investment stock in Europe and North America dominated by the United States has been rising in the past decade. After China obtains strategic assets through reverse investment, the production factors of domestic manufacturing industry can better combine with them, optimize the output portfolio, improve the efficiency of resource allocation, improve the international competitiveness of manufacturing industry, promote the development of manufacturing industry to the high end of value chain, that is, extend to both ends of "smile curve", and promote the high-quality development of manufacturing industry.

\section{An Empirical Study on the Effect of Provincial OFDI on Resource Allocation of Equipment Manufacturing Industry in China}

Due to the particularity of Tibet and the lack of economic data, this paper does not include Tibet Autonomous Region (the same below) in the empirical analysis. Firstly, using the panel data of 30 provinces in China from 2004 to 2017, this paper further analyzes the resource allocation effect of OFDI on the equipment manufacturing industry in China, so as to verify the previous reasoning analysis.

\subsection{Variable Selection and Data Sources}

\subsubsection{Explained Variable}

The explained variable is profit margin of main business (PMB). Profit margin of main business refers to the ratio of profit of main business to net income of main business in a certain period. (Profit margin of main business $=$ (main business income - main business cost - main business taxes and surcharges) $/$ main business income $^{*}$ 100). It shows how much main business profit each unit of main business income can bring, reflects the profitability of main business, and is the main index to evaluate the operating efficiency of an enterprise. According to the hypothesis of this paper, the effect of resource allocation is reflected in the reduction of production and operation costs of equipment manufacturing industry. The more effective the resource allocation is, the better the cost control is, and the stronger the profitability is, the higher the PMB is.

Therefore, this index is used to measure the effect of resource allocation. The relevant data are calculated according to the relevant data of China Industrial Economic Statistical Yearbook and China Industrial Statistical Yearbook.

\subsubsection{Explanatory Variables}

Outward foreign direct investment (OFDI) is used as the explanatory variable, and the stock data of OFDI of each province in each year is selected, which comes from the Statistical Bulletin of China's OFDI.

\subsubsection{Control Variables}

(1) Export delivery value (Ex), the export delivery value of provincial equipment manufacturing industry, reflects the export situation of enterprises and the demand of foreign markets for products. The data comes from China Industrial Economic Statistical Yearbook and China Industrial Statistical Yearbook.

(2) Enterprise scale (ES), the ratio of the total industrial output value of the provincial equipment manufacturing industry (replaced by the main business income after 2012) to the number of enterprises, reflects the scale level of the provincial equipment manufacturing industry. According to the relevant data of China Industrial Economic Statistical Yearbook and China Industrial Statistical Yearbook over the years.

(3) Employees (EM), the number of employees in the provincial equipment manufacturing industry, reflects the labor scale of the industry. The data comes from China Industrial Economic Statistical Yearbook and China Industrial Statistical Yearbook.

The descriptive statistics of each variable are shown in Table 2. 
Table-2. Descriptive statistics of variables.

\begin{tabular}{c|c|c|c|c|c}
\hline Variable & Observation & Mean & Standard deviation & Minimum & Maximum \\
\hline PMB & 420 & 14.86 & 2.292 & 7.73 & 29.57 \\
\hline OFDI & 420 & 292.2 & 823.1 & 0.08 & 9663 \\
\hline EX & 420 & 1543 & 3371 & 0.04 & 18141 \\
\hline ES & 420 & 2.222 & 1.278 & 0.277 & 6.414 \\
\hline EM & 420 & 99.65 & 151.1 & 0.91 & 765.4 \\
\hline
\end{tabular}

\subsection{Basic Model}

On the basis of the relevant literature of experts and scholars, this paper sets the following regression model.

$$
\mathrm{PMB}_{\text {it }}=\alpha+\beta_{1} \mathrm{OFDI}_{\mathrm{it}}+\beta_{2} \mathrm{EX}_{\mathrm{it}}+\beta_{3} \mathrm{ES}_{\mathrm{it}}+\beta_{4} \mathrm{EM}_{\mathrm{it}}+\varepsilon_{\mathrm{it}}
$$

Among them, $\mathrm{PMB}_{i t}$ is the main business profit margin of the equipment manufacturing industry of the $\mathrm{i}$ province in the $t$ period, that is, the ratio of main business profit to net main business income ( Profit margin of main business = (main business income - main business cost - main business taxes and surcharges) / main business income * 100); $\mathrm{OFDI}_{\mathrm{it}}$ is the total outward foreign direct investment of the i province in the $t$ period. For the influence of price factors, all OFDI values in this paper are converted into RMB prices by exchange rate, and adjusted by fixed asset investment price index; $\mathrm{EX}_{\mathrm{it}}$ is the export delivery value of the equipment manufacturing industry of the $\mathrm{i}$ province in phase $\mathrm{t}$; $\mathrm{ES}_{\mathrm{it}}$ is the enterprise model of the equipment manufacturing industry of the $i$ province in phase $t$, that is, the total industrial output value (main business income) and enterprise unit of the provincial equipment manufacturing industry. $\mathrm{EM}_{\mathrm{it}}$ is the number of employees in the equipment manufacturing industry of the i Province in the t phase. $\alpha$ is a constant term and $\varepsilon_{i t}$ is a random interference term.

\subsection{Empirical Results and Analysis}

The panel data model mainly includes fixed effect model, random effect model and mixed model. Before estimating the panel data model, it is necessary to determine which of the three models to use in advance. The empirical approach is to consider the reasonable model form according to the economic relationship of the sample space selected by the panel data. It is suitable to consider the fixed effect model. Therefore, this empirical analysis uses fixed effect model. It was mainly selected by Hausman test. In the empirical study, the individual fixed effect and time fixed effect are controlled. The specific results are shown in Table 3 and Table 4 respectively.

\subsubsection{Overall Analysis of the Whole Country}

The following table shows the empirical results of provincial level data. This paper uses the method of stepwise regression to gradually add each variable to the empirical model analysis. As shown in column (3) of Table 3 OFDI has a significant positive effect on PMB when controlling for other factors, individual effect and time effect. For each additional unit of OFDI, the profit margin of its main business will increase by 0.087 percentage points.

Table-3. Model regression results.

\begin{tabular}{|c|c|c|c|}
\hline & $(1)$ & $(2)$ & (3) \\
\hline & PMB & PMB & PMB \\
\hline \multirow[t]{2}{*}{ OFDI } & $0.00051^{* * * *}$ & $0.00069^{* * * *}$ & $0.00087^{* * * *}$ \\
\hline & $(0.000)$ & $(0.000)$ & $(0.000)$ \\
\hline \multirow[t]{2}{*}{ EX } & & 0.00041 & 0.00013 \\
\hline & & $(0.133)$ & $(0.650)$ \\
\hline \multirow[t]{2}{*}{$\mathrm{ES}$} & & $-0.32809^{* * * *}$ & 0.06820 \\
\hline & & $(0.000)$ & $(0.729)$ \\
\hline \multirow[t]{2}{*}{ EM } & & -0.00885 & -0.00024 \\
\hline & & (0.194) & $(0.973)$ \\
\hline Time effect & & & Yes \\
\hline \multirow[t]{2}{*}{ _cons } & $14.71028^{\text {****** }}$ & $15.62977^{\text {***** }}$ & $14.85565^{* * * *}$ \\
\hline & $(0.000)$ & $(0.000)$ & $(0.000)$ \\
\hline$N$ & 420 & 420 & 420 \\
\hline$R^{2}$ & 0.039 & 0.088 & 0.164 \\
\hline $\mathrm{F}$ & 15.98858 & 9.30954 & 4.31044 \\
\hline
\end{tabular}




\subsubsection{Empirical Analysis at Regional Level}

In order to further explore the impact of OFDI on PMB in different regions (eastern region, central region, western region, northeast region). In this paper, three dummy variables are set, which are Eastern, central and western, and the northeast is taken as the comparison object. Of which, OFDI_ E is the cross product of OFDI and the eastern dummy variable_ $\mathrm{M}$ is the cross product of OFDI and central region, OFDI_ $\mathrm{W}$ is the intersection of OFDI and western region. Table 4 shows the empirical results at the regional level. The effect of OFDI on PMB in different regions is the addition of OFDI coefficient and cross multiplication coefficient. The results show that the positive effects of OFDI on PMB are different in different regions. The significant impact of OFDI on PMB is 0.00604, which indicates that the growth of OFDI in Northeast China will have a significant positive impact on PMB. Secondly, the cross terms in the eastern region are significantly negative, which indicates that the positive effect in the eastern region is 0.00534 points smaller than that in the northeast region, but larger than that in the western and central regions. The coefficient of OFDI_M is significantly -0.0123, indicating that the difference between the central part and the northeast is the largest. At the same time, the coefficients of OFDI are compared with those of OFDI_ M is -0.00623 , which indicates that the effect of OFDI on PMB in Central China is significantly negative. Finally, the cross term of the western region is -0.00979, which indicates that its impact effect is significantly lower than that of the northeast region, and the overall effect is $0.00604+(-0.00979)=-0.00375$, which indicates that the impact of OFDI development on PMB in the western region is also significantly negative.

Table-4. Model regression results.

\begin{tabular}{l|c|c}
\multicolumn{3}{c}{ Table-4. Model regression results. } \\
\hline & $\mathbf{( 1 )}$ & $\mathbf{( 2 )}$ \\
\hline OFDI & PMB & PMB \\
\hline EX & $0.00480^{* *}$ & $0.00604^{* *}$ \\
\hline & $(0.007)$ & $(0.001)$ \\
\hline ES & 0.00014 & -0.00013 \\
\hline & $(0.608)$ & $(0.662)$ \\
\hline EM & -0.18408 & 0.09546 \\
\hline & $(0.051)$ & $(0.619)$ \\
\hline OFDI_E & 0.00034 & 0.00908 \\
\hline & $(0.962)$ & $(0.228)$ \\
\hline OFDI_M & $-0.00418^{*}$ & $-0.00534^{* *}$ \\
\hline & $(0.019)$ & $(0.004)$ \\
\hline OFDI_W & $-0.01169^{* * *}$ & $-0.01230^{* * *}$ \\
\hline \multicolumn{2}{|c|}{$(0.000)$} & $(0.000)$ \\
\hline Time effect & $-0.01019^{* * *}$ & $-0.00979^{* * *}$ \\
\hline cons & $(0.000)$ & $(0.000)$ \\
\hline & & Yes \\
\hline$N$ & $15.07780^{* * *}$ & $14.44202^{* * *}$ \\
\hline$R^{2}$ & $(0.000)$ & $(0.000)$ \\
\hline F & 420 & 420 \\
\hline Note: p-values in parentheses. & 0.167 & 0.227 \\
\hline${ }^{*}<0.05,{ }^{* *} p<0.01,{ }^{* * *} p<0.001$. & & 5.43516 \\
\hline
\end{tabular}

\section{Empirical Analysis on the Effect of Forward and Reverse OFDI on Resource Allocation of China's Equipment Manufacturing Industry}

In this paper, from the perspective of outward foreign direct investment target countries, two groups of countries are selected according to China's outward foreign direct investment stock in 2017. One group is the 25 typical developing countries with the largest outward foreign direct investment stock in China, including the Russian Federation, Indonesia, Kazakhstan, South Africa, Pakistan, United Arab Emirates, Thailand and Vietnam , Malaysia, India, Congo (DRC) ) Iran, Mongolia, Venezuela, Brazil, Saudi Arabia, Tajikistan, Argentina, Turkey, Ecuador, Uzbekistan, Egypt, Cyprus, Poland, Czech Republic, another group of countries are 25 typical equipment manufacturing developed countries, which are also the 25 developed countries with the largest stock of China's outward foreign direct investment, including the United States, Singapore and Australia Asia, the United Kingdom, the Netherlands, Germany, Canada, Switzerland, Sweden, South Korea, France, Israel, Japan, New Zealand, Norway, Italy, Ireland, Austria, Spain, Belgium, Hungary, Denmark, Greece, Malta, Slovakia. In 2017, the cumulative amount of China's outward foreign direct investment stock in these two groups of countries accounted for more than $85 \%$ of the total amount of China's outward foreign direct investment stock in the whole year. Through these two groups of countries, it is representative and reasonable to investigate China's forward investment in developing countries and reverse investment in developed countries, as well as the impact on the resource allocation of China's equipment manufacturing industry. 


\subsection{Data Sources and Model Construction}

Based on the data of the profit margin of main business of China's equipment manufacturing industry and China's outward foreign direct investment in the above two groups of countries from 2004 to 2017, this paper constructs a time series regression analysis model, and tests the resource allocation effect of China's OFDI in different countries on the equipment manufacturing industry one by one. The time series regression model is as follows:

$\mathrm{PMB}_{\mathrm{t}}=\alpha_{\mathrm{i}}+\beta_{\mathrm{it}} \operatorname{LOG}\left(\mathrm{OFDI}_{\mathrm{it}}\right)+\varepsilon_{\mathrm{it}}$

$\mathrm{PMB}_{\mathrm{t}}$ is the profit margin of China's equipment manufacturing industry's main business in year t, $\mathrm{OFDI}_{i t}$ is the stock of China's outward foreign direct investment in sample i countries in year $t, \alpha_{i}$ is a constant term, $\beta_{i t}$ is a coefficient, and $\varepsilon_{i t}$ is a random interference term. The data of China's outward foreign direct investment (OFDI) to the above two groups of countries are from the Statistical Bulletin of China's Outward Foreign Direct Investment, OFDI value uses fixed asset investment price index to eliminate the impact of price. The profit margin of main business (PMB) data of equipment manufacturing industry comes from China Industrial Economic Statistical Yearbook, China Industrial Statistical Yearbook and China Statistical Yearbook. Using EViews6.0 software, the estimated results of the parameters of the two groups of national regression models are shown in Table 5 and Table 6 respectively.

\subsection{Verification Results of Resource Allocation Effect of OFDI Forward Investment in Developing Countries}

According to the parameter estimation results of the regression model of developing countries in Table 5, the logarithmic coefficients of OFDI are positive, and most of them are significant (except Turkey is not significant, other countries are significant), indicating that China's forward OFDI to developing countries has a positive change relationship with the $\mathrm{PMB}$ of China's equipment manufacturing industry, and the effect of forward OFDI on resource allocation of China's equipment manufacturing industry is significant. In terms of the overall average, for every $1 \%$ increase in China's OFDI to developing countries, the PMB of China's equipment manufacturing industry will increase by $0.40 \%$.

Table-5. The regression results of resource allocation effect of OFDI on equipment manufacturing industry in China to developing countries.

\begin{tabular}{|c|c|c|c|}
\hline No. & Variable & Constant term & Log (OFDI) coefficient \\
\hline 1 & Russia & $7.5243^{*} * * * \quad(1.1601)$ & $0.4489 * * * \quad(0.0806)$ \\
\hline 2 & Indonesia & 8.3504*** (0.8334) & 0.4110 *** (0.0607) \\
\hline 3 & Kazakhstan & $9.4178^{*} * * * * \quad(1.0755)$ & $0.3305^{*} * *$ (0.0778) \\
\hline 4 & South Africa & $\left.8.68622^{* * * *} 0.8609\right)$ & $0.3810^{* * * *}$ (0.0619) \\
\hline 5 & Pakistan & $8.3203^{*} * *$ (1.0038) & $0.4182 * * *(0.0741)$ \\
\hline 6 & The United Arab Emirates & 8.2727 **** $(0.8546)$ & $0.4376^{* * * *}(0.0654)$ \\
\hline 7 & Thailand & $6.7361^{* * * *}(1.1518)$ & $0.5431 * * * \quad(0.0863)$ \\
\hline 8 & Vietnam & 6.1918**** (1.1265) & $0.5837 * * *$ (0.0844) \\
\hline 9 & Malaysia & $6.7129^{* * * *}(1.2265)$ & $0.5583^{*} * *(0.0942)$ \\
\hline 10 & India & 10.5771 米*** (0.5315) & $0.2744 * * * \quad(0.0425)$ \\
\hline 11 & Congo (DRC) & 9.6249**** (0.4941) & $0.3500 * * *(0.0395)$ \\
\hline 12 & Iran & 9.4581 **** (o.8093) & $0.3534 * * * \quad(0.0631)$ \\
\hline 13 & Mongolia & $7.2035^{*} * * *(1.0703)$ & $0.5023 * * *(0.0793)$ \\
\hline 14 & Venezuela & 9.4224**** (0.7716) & $0.3619^{*} * * \quad(0.0611)$ \\
\hline 15 & Brazil & 7.8336**** (0.8759) & $0.4774 * * *(0.0680)$ \\
\hline 16 & Saudi Arabia & 10.6671 **** $(0.9606)$ & $0.2598^{*} *(0.0751)$ \\
\hline 17 & Tajikistan & $8.6322^{*} * * *$ (o.7876) & $0.4521 * * * \quad(0.0665)$ \\
\hline 18 & Argentina & 10.2541 **** $(0.5105)$ & $0.3108 * * * \quad(0.0423)$ \\
\hline 19 & Turkey & 13.4241 **** (0.5092) & $0.0608 \quad(0.0543)$ \\
\hline 20 & Ecuador & $10.612^{*} * * * \quad(0.7812)$ & $0.2934 * * * \quad(0.0677)$ \\
\hline 21 & Uzbekistan & $9.8432^{*} * * * \quad(0.6115)$ & $0.3734 * * * \quad(0.0549)$ \\
\hline 22 & Egypt & $7.7093^{*} * * *(1.0868)$ & $0.5263^{*} * *$ (0.0912) \\
\hline 23 & Cyprus & 9.6649**** (1.1448) & $0.1904 * * * \quad(0.0552)$ \\
\hline 24 & Poland & 9.6649***** (1.1448) & $0.3857 * * *(0.1022)$ \\
\hline \multirow[t]{2}{*}{25} & Czech Republic & 10.5749 *** $(0.6347)$ & $0.3318^{* * * *}(0.0615)$ \\
\hline & Mean value & & $\begin{array}{l}\text { O.3981 (Excluding the } \\
\text { non-significant countries) }\end{array}$ \\
\hline
\end{tabular}

Note: the standard deviations of the coefficients are shown in brackets, ${ }^{*}, * *, * * *$, respectively representing the significance levels of $10 \%, 5 \%$ and $1 \%$. 
From the terms of specific countries, Vietnam (0.5837), Malaysia (0.5583), Thailand (0.5431), Egypt (0.5263) and Mongolia (0.5023) are the top five countries with significant resource allocation effect of forward OFDI on China's equipment manufacturing industry. Among them, Vietnam ranks first. Every $1 \%$ increase of China's OFDI to Vietnam will increase the PMB of China's equipment manufacturing industry by $0.58 \%$; the top three countries with the largest impact coefficient of forward OFDI are Vietnam, Malaysia and Thailand, all of which are Southeast Asian countries, indicating that China's OFDI to Southeast Asian countries has more significant impact on the resource allocation of equipment manufacturing industry, and the empirical results are more consistent with the actual situation. On the one hand, Southeast Asian countries are rich in natural resources such as rubber and coal, which is the source of China's resources. On the other hand, Southeast Asia has abundant and cheap labour resources, which is an important area for labour-intensive industrial transfer, and also the main target of efficiency seeking and market seeking OFDI. Egypt and Mongolia rank fourth and fifth in the forward OFDI impact coefficient, and their effects are also significant. These two countries are mainly rich in mineral resources, and they are also the main places for China's resource-based foreign investment. Generally speaking, China's OFDI to developing countries is largely due to its access to productive resources, especially natural resources.

\subsection{Verification Results of Resource Allocation Effect of Reverse Investment OFDI in Developed Countries}

From the parameter estimation results of the regression model of developed countries in Table 6, the logarithmic coefficients of OFDI are all positive, and most of them are significant ( except South Korea , Denmark and Spain, other countries are significant), indicating that China's reverse OFDI to developed countries has a positive change relationship with the PMB of China's equipment manufacturing industry, and reverse OFDI has a significant effect on resource allocation of China's equipment manufacturing industry. In terms of the overall average, for every $1 \%$ increase in China's OFDI to developed countries, the PMB of China's equipment manufacturing industry will increase by $0.32 \%$.

Table-6. The regression results of resource allocation effect of OFDI on equipment manufacturing industry in China to developed countries.

\begin{tabular}{|c|c|c|c|}
\hline No. & Variable & Constant term & Log (OFDI) coefficient \\
\hline 1 & U.S.A & $8.1727^{*} * *$ (0.9806) & $0.3793 * * *$ (0.0640) \\
\hline 2 & Singapore & $8.3564 * * * *(0.6542)$ & $0.3756 * * *(0.0436)$ \\
\hline 3 & Australia & $7.3725^{* * * *}(0.7985)$ & $0.4363^{* * *}(0.0527)$ \\
\hline 4 & Britain & $9.3849^{* * * *}(0.7151)$ & $0.3255^{*} * *$ (0.0505) \\
\hline 5 & Netherlands & $10.9038 * * * \quad(0.3926)$ & $0.2390 * * * \quad(0.0302)$ \\
\hline 6 & Germany & 7.3915 *** $(1.1096)$ & $0.4754 * * *(0.0800)$ \\
\hline 7 & Canada & $8.8623^{*} * *$ (0.6401) & 0.3666 *** $(0.0457)$ \\
\hline 8 & Switzerland & 11.4515 **** $(0.4837)$ & $0.2387^{* * * *}(0.0451)$ \\
\hline 9 & Sweden & $10.6006 * * *$ (o.4960) & $0.2681 * * * \quad(0.0390)$ \\
\hline 10 & Korea & 5.3867 (3.2903) & $0.6226(0.2387)$ \\
\hline 11 & France & $10.6234 * * *(0.6640)$ & $0.2592 * * *(0.0510)$ \\
\hline 12 & Israel & $11.9507 * * *$ * (0.5154) & $0.2017 * * * \quad(0.0504)$ \\
\hline 13 & Japan & $5.4683^{* * * *}(0.9432)$ & $0.6431 * * *(0.0765)$ \\
\hline 14 & $\begin{array}{l}\text { New } \\
\text { Zealand }\end{array}$ & $9.4326^{* * * *}(0.9054)$ & $0.3852^{* * *} \quad(0.0765)$ \\
\hline 15 & Norway & $12.4279 * * * \quad(0.2477)$ & $0.1481 * * * \quad(0.0225)$ \\
\hline 16 & Italy & $8.4606^{* * * *}(0.7611)$ & $0.4604 * * *(0.0634)$ \\
\hline 17 & Ireland & 12.2449 **** (0.4069) & $0.1669 * * * \quad(0.0381)$ \\
\hline 18 & Austria & $12.2320^{*} * *$ (0.3168) & $0.1937 * * *$ (0.0339) \\
\hline 19 & Belgium & $10.7058 * * *(0.4067)$ & $0.3073^{*} * *(0.0378)$ \\
\hline 20 & Hungary & $10.0909 * * * \quad(0.7531)$ & $0.3421 * * *(0.0660)$ \\
\hline 21 & Denmark & 12.1667 **** $(3.0726)$ & $0.1684 \quad(0.2877)$ \\
\hline 22 & Greece & $12.1892^{* * * *}(0.4330)$ & $0.2170^{* * *} \quad(0.0512)$ \\
\hline 23 & Spain & $1.0614 \quad(2.4338)$ & $1.0745 \quad(0.2026)$ \\
\hline 24 & Malta & $11.7744^{* * * *}(0.7183)$ & $0.2735^{* *}(0.0883)$ \\
\hline \multirow[t]{2}{*}{25} & Slovakia & $12.0182 * * *$ (o.2939) & $0.2253^{* * * *}(0.0328)$ \\
\hline & Mean value & & $\begin{array}{l}\text { 0.3149 ( Excluding the } \\
\text { non-significant countries) }\end{array}$ \\
\hline
\end{tabular}


From the terms of specific countries, the top eight developed countries with significant effect of reverse OFDI on resource allocation of China's equipment manufacturing industry are Japan (0.6431), Germany (0.4754), Italy (0.4604), Australia (0.4363), New Zealand (0.3852), the United States (0.3793), Singapore (0.3756) and Canada (0.3666), among which the highest is Japan, and every $1 \%$ increase in China's OFDI to Japan will lead to a $0.64 \%$ increase in the PMB of China's equipment manufacturing industry, which indicates that China and Japan are close neighbours with highly developed manufacturing industry. China's OFDI to Japan has achieved remarkable results in reducing production costs and improving economic benefits, especially in obtaining strategic resources such as technology patents, marketing network and management experience, which has a good resource allocation effect on the equipment manufacturing industry. The main business profit margin of the manufacturing industry has a significant impact. Then it has a significant impact on the improvement of the PMB of the equipment manufacturing industry.

In a word, whether China's OFDI to developing countries or developed countries, most of the countries have a positive and significant impact on the PMB of China's equipment manufacturing industry, which indicates that China's OFDI has a significant positive effect on the resource allocation of China's equipment manufacturing industry, and from the average value of LOG (OFDI) coefficient of the two groups of countries, the resource allocation effect of forward OFDI is greater than that of reverse investment, which indicates that the resource allocation effect of OFDI on the equipment manufacturing industry in China at the present stage is to obtain more natural resources and cheap labour resources, and it needs to be strengthened to obtain technology patents, brands and other strategic resources.

\section{Conclusions and Suggestions}

According to the panel empirical verification of China's provincial OFDI on the resource allocation effect of the equipment manufacturing industry, and the time series empirical verification results of China's forward and reverse OFDI on the resource allocation effect of the equipment manufacturing industry, we can draw the conclusion that China's OFDI has a significant positive effect on the resource allocation of the equipment manufacturing industry, and every unit of China's OFDI increases, the profit margin of the equipment manufacturing owner's business increases 0.087 percentage points. From the regional point of view, the growth of OFDI in Northeast China will have a significant positive impact on the profit margin of equipment manufacturing business, and its positive impact is the largest, followed by the eastern region, and the OFDI in the central and western regions has a significant negative impact. From the perspective of OFDI gradient, China's forward OFDI to developing countries and reverse OFDI to developed countries have a significant positive impact on the profit margin of main business of equipment manufacturing industry, and the impact on OFDI of developing countries is more significant.

Therefore, this paper puts forward the following countermeasures and suggestions: first, in view of the significant positive effect of OFDI on the resource allocation of equipment manufacturing industry in China, we should continue to implement the "capital going out" strategy, face the global market, allocate resources globally, reduce production costs, improve production efficiency, and promote the development of China's equipment manufacturing industry. Second, in view of the fact that the growth of OFDI in Northeast China has the greatest positive impact on the PMB, we should actively encourage Northeast China to increase outward foreign direct investment, promote the "going out" of equipment manufacturing industry, improve the efficiency of global resource allocation, and accelerate the transformation and upgrading of equipment manufacturing industry in the old industrial bases in Northeast China. Third, in view of the fact that the growth of OFDI in the central and western regions has a significant negative impact on the PMB, and OFDI has a capital "crowding out effect", the current shortage of funds in the central and western regions should be adjusted to local conditions, and the scale of outward foreign direct investment should be reasonably controlled, so as not to affect the transformation and upgrading of equipment manufacturing industry in these regions. Fourth, in view of the more significant effect of OFDI on the resource allocation of equipment manufacturing industry in China to developing countries, China should put more investment in ASEAN countries and those along the Belt and Road so that the international capacity cooperation be strengthened and the allocation of resources be optimized. Fifth, we should steadily promote outward foreign direct investment in developed countries, obtain strategic resources through various channels and ways, strengthen digestion and absorption, and improve core international competitiveness.

\section{References}

Adler, M. (1974). The cost of capital and valuation of a two-country FIRM $[$ M $] / /$. The Journal of Finance, 29(1), $119-132$.

Bai, J., \& Liu, Y. (2018). Can outward foreign direct investment improve China's resource mismatch. China's Industrial Economics, 1, 60-78.

Cao, H. (2017). Research on the impact of China's outward foreign direct investment on the development of advanced manufacturing industry. Ph.D. Dissertation. Wuhan: Wuhan University.

Chen, Y., \& Hu, W. (2011). Price distortion, factor mismatch and efficiency loss: Theoretical and applied. China Economic Quarterly, 10(4), 1401-1422.

Dai, X. (2006). An empirical analysis of the impact of outward foreign direct investment on domestic employment: A case study of Singapore. World Economic Research, 4, 70-76. 
Dunning, J. H. (1977). Trade, location economic activity and the MNE: A search for an eclectic approach. London: Palgrave Macmillan.

Gong, G., \& Hu, G. (2013). Resource allocation efficiency and total factor productivity of China's manufacturing industry [J]. Economic Research, 48(4), 4-15.

Guo, F., \& Huang, Y. (2012). Research on the transmission mechanism of reverse technology spillover effect of OFDI from the perspective of global value chain: A case study of Huawei Technology Co., Ltd. Journal of Management, 25(3), 61-65.

Guo, P. (2017). Research on the impact of industrial transfer on resource mismatch. M.A. Thesis. Changsha : Hunan University of Science and Technology.

Han, Y., \& Wang, L. (2016). The impact of OFDI reverse technology spillover on China's energy efficiency. Economic Issues, 3, 95-101.

Hiley, M. (1999). The dynamics of changing comparative advantage in the Asia -Pacific Region. Journal of the Asia Pacific Economy, 4, 446-467.

Hu, B. (2017). Resource mismatch of China's manufacturing industry and its impact on total factor productivity. M.A. Thesis. Harbin: Harbin University of Commerce.

Huo, X. (2014). Research on the adjustment effect of China's OFDI industrial structure -- An Empirical Analysis Based on grey correlation theory. International Economy and Trade Research, 30(9), 24-32.

IMF. (2001). Foreign direct investment statistics: How countries measure (Vol. 23). Washington D.C: FDI.

Ji, S., Zhu, Y., \& Zhang, X. (2016). Research on the improvement effect of industrial agglomeration on resource mismatch. China Industrial Economics, 6, 73-90.

Kogut, B., \& Chang, S. (1991). Technological capabilities and Japanese foreign direct investment in the United States. The Review of Economics and Statistic, 73(3), 401-413.

Kojima, \& Zhou, B. (1987). On foreign trade: Nankai University Press.

Lai, Y. (2019). Research on the impact of outward foreign direct investment on China's resource allocation efficiency. M.A. Thesis. Beijing: Beijing Jiaotong University.

Li, X., \& Wang, Z. (2015). The effect of foreign direct investment on home country trade structure -- Based on the analysis of China's provincial panel data. Exploration of Economic Problems, 393(04), 138-144.

Lin, G., \& Chen, T. (2020). The impact of outward foreign direct investment on industrial resource allocation efficiency: A case study of agricultural processing industry. World Economic Research, 7, 46-59.

Liu-Mingxia. (2010). Reverse technology spillover effect of China's FDI: An analysis based on technology gap. Journal of Zhongnan University of Economics and Law, 180(3), 16-21.

Ministry of Commerce. (2008). Statistical bulletin of China's foreign direct investment in 2007 (pp. 42): Ministry of Commerce.

Potterie, B. P., \& Lichtenbe. (2001). Does foreign direct investment transfer technology across borders? Review of Economics and Statistics, 83(3), 490-497.

Song, Y. (2015). Research on the reverse technology spillover effect of China's Foreign Direct Investment: Theoretical model and empirical test. Economic Survey, 32(3), 60-65.

Teece, D. J. (1992). Foreign investment and technological development in Silicon. California Management Revierw, $34(2), 88$.

United Nations Conference on Trade and Development World Investment Report. (1996). Beijing: University of Foreign Economic Relations and Trade Press.

Xie-Qiaoxin. (2014). Research on the effect of OFDI on the capital allocation efficiency of home country -- Based on the provincial panel data of China. Journal of Industrial Technology Economy, 245(3), 71-76.

Yang, J. (2004). The impact of outward foreign direct investment on home country employment. Business Era (Theoretical Edition), 35, 61-62.

Yu-Guansheng. (2014). Foreign direct investment motives of enterprises in developed and developing countries: A comparative study based on literature review. Journal of Hubei University of Economics, 12(06), 40-46.

Zhang, Y., \& Wu, X. (2017). Factor flow in international direct investment and resource allocation in global economy. Academic Monthly, 49, 78-89.

Zhang, C., \& Zhao, G. (2018). Estimation of the distortion degree of China's regional resources. Shanghai Economic Research, 03, 32-43. 